\title{
The importance of transversal competencies in academic success: the cognitive flexibility
}

\author{
Cristina Gama Guerra; Gastão Marques. Instituto Politécnico de Portalegre. cristinag@ipportalegre.pt
}

\section{Introduction}

There is a growing recognition of the importance of soft-skills for behavior effectiveness in the 21st century (Binkley et al., 2012, Lippman et al., 2006, Delors et al., 1996; Gordon et al., 2009). In this paper, we try to understand the effectiveness of cognitive flexibility, as transversal competence, in academic success. In determining academic success, there are many variables: socioeconomic factors (Albernaz et al., 2002); emotional, motivational and personality aspects (Gottfried, 1985; Lloyd \& Barenblatt, 1994; Marturano \& cols 1993); teachers' and students' strategies (Boruchovitch, 1999; Sousa \& Santos, 1999) beliefs (Kember, 2001; Shinogaya, 2008); selfconception (Guay \& cols 2003; Marsh \& Yeung, 1997), self-perception (Gose \& cols, 1980; Schicke \& Fagan, 1994), general intelligence. (Gagne \& St Pére, 2002; Gottfredson, 2002). In some studies, the importance of cognitive flexibility for solving academic problems appears to show influence (Bull \& Scerif, 2001; Deák 2003; Jacques \& Zelazo, 2005). With this work, we wanted to contribute to the development of this research.

\section{Sample}

This study included a sample of 603 Portuguese public higher education students. Of the respondents, $81.4 \%$ were females and $18.6 \%$ males, aged between 18 and 57 years $(\mathrm{M}=$ 21.51; SD = 4.76). The data collection was carried out in six different institutions of Portuguese higher education. Respondents have an average entrance mark in higher education of 13.98 (SD = 1.37) and a current average mark during the attendance course of $13.41(S D=1.27)$.

\section{Measures}

Proof of Cognitive Flexibility Performance (PDFC, Guerra, 2012); Advanced Raven-E Progressive Matrices (MPAR-E, Raven, Raven \& Court, 1998); Wechsler Adult Intelligence Scale -WAIS III; Adapted Scale of Selfperception of Cognitive Flexibility (EFC, Guerra, 2012); Adapted Scale of Self-perception of Functional Intelligence (APIq, Guerra, 2012); Emotional Intelligence View 360 Questionnaire, (EIQV, Nowack 1997); Situational Competence Perception Test (TPCS, Candeias, 2001: Candeias \& Almeida, 2005)

\section{Methodology}

To study the predictive power of cognitive flexibility in the academic success, we performed multiple linear regression studies (stepwiser procedure), using the formula, $y=. a+\beta x i+€$.

Table 1. regression analysis academic success

\begin{tabular}{cccccc}
\hline $\begin{array}{c}\text { dependent } \\
\text { variable }\end{array}$ & $\begin{array}{c}\text { Independent } \\
\text { variable }\end{array}$ & beta coefficien & $\mathrm{t}$ & $\mathrm{p}$ & $\mathrm{R}$ part \\
\hline $\begin{array}{c}\text { average mark } \\
\text { of access to } \\
\text { higher }\end{array}$ & TPDFC &, 242 & 5.143 &, 000 & $34,1 \%$ \\
education & TWAIS &, 132 & 2,813 &, 000 & $2,3 \%$ \\
$\begin{array}{c}\text { current } \\
\text { average mark }\end{array}$ & TPDFC & $, 24,2862$ & 4,577 &, 000 & $27,1 \%$ \\
in the course & EFI &, 344 & 4,212 &, 000 & $7,4 \%$ \\
$\begin{array}{c}\text { marks of maths } \\
\text { of the 12th }\end{array}$ & EIQV &,- 286 & $-4,170$ &, 00 & $4,3 \%$ \\
grade students & EPDC &, 190 & 2,932 &, 005 & $2,9 \%$ \\
$\begin{array}{c}\text { marks of } \\
\text { portuguese of }\end{array}$ & TPDFC &, 153 & 3,869 &, 000 & $21,4 \%$ \\
the 12th grade & TMPAR -E &, 147 & 2,572 &, 002 & $4,7 \%$ \\
students & API &, 143 & 2,831 &, 000 & $27,3 \%$ \\
& WAIS &, 133 & 2,516 &, 000 & $6 \%$ \\
\hline
\end{tabular}

In order to test if the model fits to our intention, we took into account the value of the adjusted coefficient of determination (Ra2), following the recommendations of Maroco (2003). The regression analysis took as dependent variable the academic success. Besides, we assumed as a measure of academic success the average mark of access to higher education, the current average mark in the course and we also took as reference the marks of Maths and Portuguese of the 12th grade students. Moreover, we considered as predictive variables the cognitive flexibility as a mental process through the total of the PDFC and the totals of the EFC tests, AP (q); EIQV, WAIS - subscale understanding; MPAR -E, and the TPCS subscales) and sociodemographic variables (sex, age, course, School / University, qualifications and professional situation of the parents).

For each of the models the equations found were: (i) entrance mark in higher education, R2 $=36.47(F=77.970, p<0.001)$; (ii) current mark, $R 2=41.7(F=87.450, p<0.001)$; (iii) 12th grade Maths mark, $R 2=26,1(F=63,133$; $\mathrm{p}<, 001$ ); and (iv) 12th grade Portuguese mark, $R 2=43.2(F=84,552 ; p<0.05)$.).

In the Table 1, taking into account each of the variables that were considering in the equations, are presented the respective regression coefficients (beta coefficient), the $t$ and $p$ statistics values, as well as the change in $R 2$ values, according to each variable found in the equation (part correlation).

\section{Conclusion}

Within the models found for academic intelligence, cognitive flexibility as a mental process is common to all of them, and is responsible for the highest magnitude of the explained variance, allowing us to state that cognitive flexibility predicts academic success.

\section{Some References}

Albernaz, A., Ferreira, F. H. G., \& Franco, C. (2002). Qualidade e equidade no ensino fundamental brasileiro. Pesquisa e Plenejamento econômico, 32 Boruchovitch, E. (1999). Estratégias de aprendizagem e desempenho escolar. consideraçoes para a prâlica educacional. Psicologia, Rellexão e Crilca, $12(2), 361-376$.

(2001). Executive functioning as a predictor of children's Exitch Developmental Neuropsychology, 193(3), 273-293. Dáak, G. O. (2003). The development of cognitive flexibility and language abilities. In R. Kail (Ed.), Advances in Child Development and Behavior (Vol. 31, pp. 271-327). San Diego, CA: Academic Press. motivation still . 30 (1) 71-100.

S. \& Muler, D. (1980). The relative potential os selfconcept and intelligence as predictors of achievement. Journal of Psychology, 104, 279, 287. Sternberg \& E. L. Grigorenko (Eds), The general factor of intelligence: how general is it?. (p. 331-380). Mahwah. Gottfried, A. E. (1985). Academic intrinsic motivation in elementary and junior high school students. Journal of Educational Psychology, 77, 631-645. 